\title{
Public Interest Groups, Public Law Litigation, and Federal Rule 24(a)
}

\author{
Cindy Vreeland $\dagger$
}

The Supreme Court's decision in Brown $v$ Board of Education $^{1}$ stands as a benchmark in two great revolutions. The first was social: the forced integration of schoolchildren played a key role in the struggle for racial equality. The second was judicial. In Brown, the Supreme Court "committed the federal courts to an enterprise of profound social reconstruction." Other forms of nontraditional litigation soon followed, such as challenges to legislative districting, suits assailing practices of mental hospitals and police departments, environmental enforcement aciions, and constitutional attacks on government expenditures and statutes. ${ }^{3}$

In his seminal article, Professor Abram Chayes identified these cases with the emergence of a new model of litigation: "public law litigation." $\mathrm{He}$ contrasts traditional litigation, which he characterizes as a mode of settling private disputes, with public law litigation, which instead centers on a "grievance about the content or conduct of policy-most often governmental policy, but frequently the policy of nongovernmental aggregates." Public law cases usually set out "to vindicate important social values that affect numerous individuals and entities." According to Professor

† B.A. 1987, Baylor University; J.D. Candidate 1990, The University of Chicago.

347 US 483 (1954) (Brown I: finding segregation of schools unconstitutional); and 349 US 294 (1955) (Brown II: upholding broad powers of court to remedy segregation).

2 Abram Chayes, The Supreme Court 1981 Term-Foreword: Public Law Litigation and the Burger Court, 96 Harv L Rev 4, 6 (1982). See also Richard H. Fallon, Of Justiciability, Remedies, and Public Law Litigation: Notes on the Jurisprudence of Lyons, 59 NYU L Rev 1, 1-3 (1984).

3 See, for example, Baker v Carr, 369 US 186 (1962) (voter attack on legislative districting); Mills $v$ Rogers, 457 US 291 (1982) (right of mental patients to refuse treatment); United States v SCRAP, 412 US 669 (1973) (citizen challenge of ICC order for failure to include environment impact statement); Rizzo $v$ Goode, 423 US 362 (1976) (citizen challenge of police procedures); and Flast $v$ Cahen, 392 US 83 (1968) (taxpayer challenge to use of federal funds for religious education materials).

- Abram Chayes, The Role of the Judge in Public Law Litigation, 89 Harv L Rev 1281, 1281-84 (1976).

- Chayes, 96 Harv L Rev at 4-5 (cited in note 2); and Chayes, 89 Harv L Rev at 128184.

- Carl Tobias, Public Law Litigation and the Federal Rules of Civil Procedure, 74 Cor- 
Chayes, the primary attributes of public law litigation follow from this distinction. These cases often involve sprawling party structures, an emphasis on legislative factfinding, prospective relief, ongoing decrees that affect widespread interests, and active involvement by judges.

Although some commentators have debated its legitimacy, ${ }^{8}$ public law litigation remains a significant phenomenon with which federal courts must contend. Adoption of the Fourteenth Amendment and the passage of legislation facilitating constitutional claims and creating statutory rights and remedies have increased the situations in which courts are called upon to render judgments affecting widespread social interests. ${ }^{9}$ In addition, Congress frequently relies on the courts to monitor executive enforcement of its statutory schemes by combining indefinite delegations with provisions for judicial review. ${ }^{10}$ Public law litigation is now rooted in "legal consciousness," or the way in which our society thinks about law and the legal system."

Because public law cases usually involve high stakes and widespread impacts, their adjudication often "call[s] for adequate representation in the proceedings of the range of interests that will be affected by them."12 Public interest groups have been instrumental

nell L Rev 270, 270 n 1 (1989).

${ }^{7}$ Chayes, 89 Harv L Rev at 1302 (cited in note 4); Chayes, 96 Harv L Rev at 5 (cited in note 2). Professor Chayes's work has spawned a significant body of literature. Some commentators have questioned the prevalence of public law litigation. See, for example, Arthur R. Miller, Of Frankenstein Monsters and Shining Knights: Myth, Reality, and the "Class Action Problem," 92 Harv L Rev 664, 692 \& nn 124-27 (1979). Others disagree about the defining features of public law litigation. See, for example, Tobias, 74 Cornell L Rev at 340 (cited in note 6). However, virtually all commentators agree that these nontraditional cases raise new, significant issues.

${ }^{8}$ See, for example, Tobias, 74 Cornell $\mathrm{L}$ Rev at $271 \mathrm{n} 2$.

- William Burnham, Aspirational and Existential Interests of Social Reform Organizations: A New Role for the Ideological Plaintiff, 20 Harv CR-CL L Rev 153, 153 (1985). Professor Burnham cites the following as examples of legislation creating private enforcement mechanisms: 42 USC $\S 1983$ (1982) (civil actions for deprivation of constitutional rights); 42 USC $\S 2000$ a (1982) (discrimination in public accommodations); 42 USC $\S 2000 \mathrm{e}$ (1982) (employment discrimination); 42 USC $\S 3601$ (1982) (housing discrimination); and 42 USC $\S 1997$ (1982) (rights of persons confined to institutions). Id at 4.

${ }_{10}$ Edward Levi, The Business of the Courts: A Summary and a Sense of Perspective, 70 FRD 79, 214 (1976).

${ }^{11}$ Chayes, 96 Harv L Rev at 8 (cited in note 2).

${ }^{12}$ Chayes, 89 Harv L Rev at 1310 (cited in note 4). See also Jack B. Weinstein, Litigation Seeking Changes in Public Behavior and Institutions-Some Views on Participation, 13 UC Davis L Rev 231, 246 (1980); and Emma Coleman Jones, Litigation Without Representation: The Need for Intervention to Affirm Affirmative Action, 14 Harv CR-CL L Rev 31, 87 (1979). 
in filling this role. ${ }^{13}$ Over the years, they have grown dramatically in number and in political power, and they have turned to the courts to pursue objectives unachievable through political processes. ${ }^{14}$ Brown $v$ Board of Education exemplifies the involvement of public interest groups in many of the Supreme Court's landmark decisions. Thurgood Marshall represented the appellants before the Court as an attorney for the NAACP; the American Jewish Congress, the ACLU, and the American Federation of Teachers filed supporting amicus curiae briefs. ${ }^{15}$

As in Brown, public interest groups have achieved many of their greatest successes by serving as legal counsel to parties and by submitting amicus briefs. Federal Rule of Civil Procedure 24(a) offers a third route by which public interest groups may participate in litigation. It requires a court to permit intervention upon demonstration by the applicant of a sufficient stake in the outcome of the litigation. ${ }^{18}$

This Comment explores intervention by public interest groups in public law cases under Rule 24(a). Section I briefly describes Rule 24 and examines the standards that various federal circuits use to decide whether a public interest group may intervene in a case. Section II argues that a court should weigh the interests behind Rule 24(a) differently when a public interest group seeks to intervene in a public law case. Finally, section III proposes a

${ }^{13}$ Although numerous and diverse organizations could fall under the rubric of "public interest group," this Comment focuses on those organizations that advocate policies affecting diffuse and widespread interests-for example, the NAACP, the ACLU, the Environmental Defense Fund, and the National Rifle Association. Under this definition, public interest groups may be distinguished from special interest groups, which advocate policies that primarily affect their own members. A trade association is an example of a special interest group.

14 NAACP v Button, 371 US 415, 429-30 \& n 12 (1963). See also Karen Orren, Standing to Sue: Interest Groups in the Federal Courts, 70 Am Pol Sci Rev 723, 724 (1976); and Samuel Krislov, The Amicus Curiae Brief: From Friendship to Advocacy, 72 Yale L J 694, 710 (1963). For a history of the development of public interest legal groups and public interest law, see Robert A. Baum, Public Interest Law: Where Law Meets Social Action 44-60 (Oceana, 1987); and Council for Public Interest Law, Balancing the Scales of Justice: Financing Public Interest Law in America 19-70 (1976).

${ }^{15}$ Brown I, 347 US at 485. Supreme Court cases in the last two decades have increased the ability of public interest groups to participate in litigation. See NAACP $v$ Button, 371 US 415. The Court has allowed greater interest group participation in litigation by broadening its standing doctrine to include such groups and by rarely denying motions by public interest groups to appear as amicus curiae. See, for example, Sierra Club v Morton, 405 US 727, 738-40 (1972); United States v SCRAP, 412 US 669, 686-87 (1973); and Karen O'Connor and Lee Epstein, Court Rules and Workload: A Case Study of Rules Governing Amicus Curiae Participation, 8 Just Sys J 35, 40 (1983).

${ }^{18}$ Rule 24(a) is set forth on the next page. 
framework for analyzing motions to intervene by public interest groups in public law litigation.

\section{The Current Status of Intervention by Public Interest Groups UNDER RuLE 24(A)}

\section{A. Rule 24}

There are two situations in which an outsider may want to intervene in an existing lawsuit. It might want to participate in litigation that could adversely affect its legal rights or other interests (a "necessity" rationale). Or, it might want to adjudicate its legal claims with similar claims in order to minimize litigation costs (an "economy" rationale). Rule 24 provides for mandatory intervention in the first situation, and discretionary intervention in the second. Rule 24(a) allows intervention of right

when the applicant claims an interest relating to the property or transaction which is the subject of the action and the applicant is so situated that the disposition of the action may as a practical matter impair or impede the applicant's ability to protect that interest, unless the applicant's interest is adequately represented by existing parties. ${ }^{17}$

Although this provision expressly addresses the interests only of the outsider, the presence in Rule 24(a) of language employed in the Rule 19 joinder provisions suggests that, as with joinder, the drafters also intended courts to consider the interests of the original parties and the courts' own concerns in ruling on motions to intervene. ${ }^{18} \mathrm{By}$ evaluating the three underscored requirements of Rule 24(a)-interest, impairment, and inadequate representation-courts can determine whether an outsider's interests are strong enough to tip the scales in favor of intervention. When the requirements are met, the court must admit the intervenor into the litigation.

An alternative to Rule 24(a) intervention exists in Rule 24(b), which allows intervention upon the court's discretion "when an ap-

17 FRCP 24(a) (emphasis added).

${ }_{18}$ James W. Moore, Jo Desha Lucas, and George J. Grotheer, Jr., 3B Moore's Federal Practice โ 24.07[1] at 24.52 (Matthew Bender, 2d ed 1987) ("Moore's"). See also United States v Hooker Chemicals, 749 F2d 968, 982-83 (2d Cir 1984) and Atlantis Development Corp. $v$ United States, 379 F2d 818, 824 (5th Cir 1967). It is not clear how much weight should be given to the interest of the outsider relative to the original parties and the courts. Compare John E. Kennedy, Let's All Join In: Intervention Under Federal Rule 24, $57 \mathrm{Ky} \mathrm{L}$ J 329, 330-31 (1969) with Jones, 14 Harv CR-CL L Rev at 56 (cited in note 12). 
plicant's claim or defense and the main action have a question of law or fact in common."18 Because this provision is based on economy rather than necessity considerations, it permits intervention even when the outsider's interests are not threatened by non-participation in the adjudication. But for the same reason-because Rule 24(a) intervention derives from economy, not need-a judge may deny the intervention when it would "unduly delay or prejudice the adjudication of the rights of the original parties."20

Public interest groups generally prefer intervention of right to permissive intervention, fearing that judges will exercise their discretion under Rule 24(b) to defeat motions for intervention when hostile to the underlying claim. ${ }^{21}$ Moreover, the reasons for which public interest groups move to intervene are usually more aligned with the theory behind intervention of right: public interest groups intervene to represent affected outsiders in lawsuits that will have an extended impact, not to save resources by joining in existing litigation rather than initiating their own. This Comment will therefore focus on Rule 24(a).

\section{B. Judicial Interpretations of Rule 24(a)}

Lack of guidance in the Advisory Committee Notes and a paucity of Supreme Court decisions on intervention of right have resulted in widely varying interpretations of the Rule 24(a) requirements. Intervention by public interest groups implicates two general splits in opinion among the federal courts of appeals. The first involves the rule's interest requirement. Some circuits require that the outsider claim a "litigable" interest-that is, an interest sufficient to confer standing and a cause of action on the intervenor in an independent lawsuit-while others require a less tangible interest. ${ }^{22}$ This difference is critical to public interest groups, whose concerns often would not support an independent suit.

The second dispute relates to the burden of proving inadequate representation. When an outsider moves to intervene on behalf of the government (or on the same side as the government), most circuits require an especially strong showing of inadequacy of representation. The presumption is that the government, in its

19 FRCP 24(b).

${ }^{20}$ Id.

${ }^{21}$ The practice of strictly construing procedural provision when hostile to the underlying claim but relaxing them when sympathetic has been referred to as "insulated justice." Jones, 14 Harv CR-CL L Rev at $47^{\circ}$ (cited in note 12).

${ }^{22}$ See text at notes 33-55. 
representative capacity, protects the interests of all citizens, including the public interest group and its members. Because public interest groups often assert interests in suits to which the government is a party, the higher burden erected in many circuits poses an additional obstacle to their intervention.

The third requirement for intervention under Rule 24(a) is that the applicant's interest will be impaired absent intervention. Whether the intervenor is a private individual or a public interest group, the impairment requirement is usually met when the litigation is likely to significantly affect the interest. ${ }^{23}$ Thus, if a public interest group's concern for integrated schools is significant enough to satisfy the interest requirement, litigation to desegregate schools would constitute sufficient threat of impairment. When an outsider asserts a non-litigable interest in the litigation, the possibility of impairment is especially clear because the outsider will have no recourse through a separate suit. Because the impairment requirement presents no unique issues in the public interest group context, this Comment will not address it in detail. The following subsections examine the interest and inadequate representation requirements.

\section{The interest requirement.}

In its first major decision construing the current version of Rule 24(a), the Supreme Court gave a broad reading to the interest requirement. Cascade Natural Gas Corp. v El Paso Natural Gas $\mathrm{Co}^{24}$ centered on El Paso's divestiture of Pacific Northwest Pipeline Corporation for antitrust reasons. The Court allowed intervention by the State of California, Southern California Edison (a large industrial user of natural gas), and Cascade Natural Gas (a distributor of natural gas), reasoning that each of these intervenors had an interest in retaining competitive conditions in the California natural gas market, and that Cascade-as a distributor supplied

\footnotetext{
${ }^{23}$ The only source of contention among the courts on the impairment requirement is whether stare decisis itself is sufficient impairment. The possibility exists that a public interest group, denied intervention in Suit A, will bring a separate and subsequent suit B in which it faces a court that is bound by the precedential force of the decision rendered in suit A. Most courts agree that stare decisis satisfies the impairment requirement, but only when the first lawsuit can realistically be expected to determine the outcome of subsequent litigation. See generally Atlantis Development Corporation v United States, 379 F2d 818, 826-29 (5th Cir 1967); and 3B Moore's II 24.07[3] at 24.63 and cases cited therein (cited in note 18). Note that this debate only concerns public interest groups asserting litigable interests, since the effect of stare decisis is felt only by a group subsequently initiating a second suit.

24386 US 129 (1967).
} 
solely by Pacific Northwest-had a particular interest in the viability of Pacific Northwest. ${ }^{25}$

The Court narrowed the interest requirement in its next decision, Donaldson $v$ United States. ${ }^{26}$ In Donaldson, a taxpayer moved to intervene in an enforcement proceeding through which the Internal Revenue Service sought production of his employment records from his employer. ${ }^{27}$ The Court upheld denial of the motion to intervene, noting that the only interest asserted by the taxpayer was his desire to prevent his employer from complying with the summons. According to the Court, this desire was not a "significantly protectable interest" as required by Rule $24(\mathrm{a}) .^{28}$

The Court's succeeding cases have failed to define "significantly protectable interest." The most important question is whether the term is meant to require a litigable interest. Shortly after Donaldson, the Court permitted intervention even though the applicant lacked a litigable interest. In Trbovich $v$ United Mine Workers of America, ${ }^{29}$ a union member sought to intervene in an action brought by the Secretary of Labor to invalidate a union election under the Labor-Management Reporting and Disclosure Act. The member had initiated the proceeding by filing a complaint with the Secretary; he also wanted to intervene to present evidence and argument in support of the Secretary's position. ${ }^{30}$ The Court allowed intervention even though the statute gave the Secretary of Labor an exclusive right to bring suit, reasoning that intervention in a lawsuit poses different concerns from initiation of a lawsuit. ${ }^{31}$

${ }^{25}$ Id at 132-33. For commentary see John E. Kennedy, $57 \mathrm{Ky}$ L J 329, 340-42 (cited in note 18); and David L. Shapiro, Some Thoughts on Intervention Before Courts, Agencies, and Arbitrators, 81 Harv L Rev 721, 722, 729-30 (1968).

26400 US 517 (1971).

${ }^{27}$ Id at 521.

28 Id at 531 .

29404 US 528 (1972).

so Id at 529-30. The member also sought to urge two additional grounds for invalidating the election. The Court disallowed these claims because the legislative history of the statute indicated that Congress intended the Secretary to perform a screening function in order to protect the unions from frivolous litigation and to centralize any proceedings. The Court believed that allowing the additional claims would circumvent this screening function. Id at 537.

s1 Id at 536 and 7. Initiating a suit imposes much greater burdens on the court and the defendant, and raises Article III concerns. See text at notes 52-55. The Court's comments on the differences between intervention and initiation came in response to a contention by the Secretary that the relevant statute barred intervention. The Secretary conceded that the union member had an interest sufficient under Rule 24(a), although it is clear from the opinion that the member did not have a litigable interest. 
In a recent opinion involving a challenge to the Illinois Abortion Law of 1975, Diamond $v$ Charles, the Court expressly declined to decide whether intervention under Rule 24(a) requires a litigable interest. ${ }^{32}$ The Court at no point cited its earlier opinion in Trbovich.

a. A litigable interest as a factor in intervention. A "litigable" interest is one that would support an independent law suit, which in turn requires constitutional standing and a cause of action. Currently, standing is said to require a "personal injury fairly traceable to the defendant's allegedly unlawful conduct and likely to be redressed by the requested relief."33 A party has a cause of action when entitled to a remedy by a common-law principle or a statutory or constitutional provision. ${ }^{34}$ The Supreme Court imposes an additional representational requirement when an organization initiates a suit on behalf of its members, under what is known as associational standing: the organization must show that "(a) its members would otherwise have standing to sue in their own right; (b) the interests it seeks to protect are germane to the organization's purpose; and (c) neither the claim asserted nor the relief requested requires the participation of individual members in the lawsuit."35

The existence of a litigable interest is an important consideration in an intervention decision because it is an outsider's ability to bring a separate suit that provides one measure of the significance of its interest under Rule 24(a) and that threatens judicial resources under Rule 24(b). Some of the strongest cases for interven-

${ }^{32} 476$ US 54, 57-61 (1986). Specifically, the majority refused to decide whether an intervenor must meet the constitutional Article III standing requirements in addition to Rule 24(a)'s requirements. However, the inquiries into standing and the existence of a litigable interest were the same in the particular case. See note 34 . The issue before the Court was whether an intervenor had the right to appeal an adverse judgment in the absence of the original defendant.

s3 Allen $v$ Wright, 468 US 737, 751 (1984).

34 To the extent that Congress can create redressable injuries by creating new legal rights, constitutional standing and the existence of a cause of action are essentially the same. See Diamond, 476 US at 65 n 17. But some recent Supreme Court decisions suggest that the two may diverge when the causal connection between right and remedy is particularly weak. Congress can define an injury by creating a legal right, but cannot create the causal requirements of "injury fairly traceable" to the defendant's conduct and likely to be redressed by a judicial proceeding. Allen, 468 US at 752 . See Cass R. Sunstein, Standing and the Privatization of Public Law, 88 Colum L Rev 1432, 1474-80 (1988).

35 Auto Mobile Workers v Brock, 477 US 274, 282 (1986), quoting Hunt v Washington State Apple Advertising Commission, 432 US 333, 343 (1977). Note that this additional requirement does not apply when the organization claims an interest as an organization, rather than as a representative of its members. 
tion to protect outside interests occur when a judgment will have a binding effect on the outsider, when an outsider claims an interest in a limited fund subject to disposition by the court, or when a case might result in a decree that could conflict with a decree later awarded to the outsider. ${ }^{36}$ Intervention is justified in these instances because resolution of the dispute may actually or effectively deprive the outsider of the right to pursue his own legal or constitutional claim. Finally, the presence of a litigable interest is especially significant in statutory cases because Congress's creation of a cause of action indicates its intent that the courts protect the interest.

But the existence of a litigable interest is only one measure of practical adverse effect on an outsider under Rule 24(a) ${ }^{37}$ Consider, for example, the interest of a lobbying group in a suit challenging the constitutionality of a law that the group sponsored. The group has no cause of action, because it could not assert a legal claim against either of the original parties to the action, yet the litigation could completely undermine the group's lobbying activities $^{38}$ and might deprive the court of the full representation of a cause that involves the public interest.

b. A litigable interest: is it required of intervenors? The Supreme Court's decisions have generated a confused body of case law in the circuit courts. Several circuits have held that Rule 24(a) requires a litigable interest, ${ }^{38}$ although some of these have expressed willingness to construe the interest requirement flexibly in public law cases. For example, the District of Columbia Circuit has reasoned that Rule 24(a) was designed for "ordinary civil litigation" and might require "other than literal application in atypical

36 See generally Shapiro, 81 Harv L Rev at 731-34 (cited in note 26). For examples involving public interest groups, see Adams $v$ Mathews, 536 F2d 417, 418 (DC Cir 1976); and United States v Reserve Mining Co., 56 FRD 408, 417-19 (D Minn 1972).

${ }^{37}$ Contrast Rule 24(b), where the existence of a litigable interest is critical, since courts and litigants achieve economy gains by combining suits only when the applicant for intervention has the ability to initiate a second suit. It is thus significant that only Rule 24(b) is phrased in terms of "claims" and "defenses."

38 This was the situation in Keith v Daley, 764 F2d 1265 (7th Cir 1985) (suit challenging legislation for which the anti-abortion group had lobbied). See also the examples in Shapiro, 81 Harv L Rev at 737-38 (cited in note 26).

${ }^{30}$ See, for example Southern Christian Leadership v Kelley, 747 F2d 777, 780-81 (DC Cir 1984); United States v American Telephone and Telegraph Co., 642 F2d 1285, 1291 (DC Cir 1980); Wilderness Society v Morton, 463 F2d 1261, 1262 (DC Cir 1972); and Francis v Chamber of Commerce of the United States, 481 F2d 192, 195 n 7 (4th Cir 1973). Contrast Chiles v Thornburgh, 865 F2d 1197, 1213 (11th Cir 1989) (intervening party need not meet standing requirements in addition to Rule $24(\mathrm{a})$ requirements). 
cases." ${ }^{40}$ Along the same lines, a District of Minnesota court perceived its proper role in one case as that of an administrative tribunal, thereby enabling it to consider numerous interests in evaluating intervention requests. ${ }^{41}$

The Seventh and Ninth Circuits have heard the largest number of cases involving public interest groups but have developed radically different standards for evaluating their motions to intervene. The Seventh Circuit narrowly interprets Rule 24(a), requiring that public interest groups, like other applicants for intervention, show a "direct, significant, and legally protectable" interest in property or a transaction at issue in the case. ${ }^{42}$ The interest must implicate a legal right of the outsider and be so direct that the outsider could maintain a separate claim. ${ }^{43}$

In some circumstances, the Seventh Circuit requires an even greater interest for intervention than is necessary for standing. The Supreme Court has recognized that aesthetic and environmental harms to a group's members may confer standing, even when the injuries are diffuse and widespread. ${ }^{44}$ Yet the Seventh Circuit has denied intervention to an environmental group which almost certainly had standing under the Supreme Court's test, reasoning that "there is a qualitative difference between the 'interest' which is sufficient for standing under the APA" (relevant in most suits challenging regulatory action) and the interest required by Rule 24(a). ${ }^{45}$ The Seventh Circuit's interpretation implies that Rule 24(a) requires more than a litigable interest, and thus that congressional intent to create a legal right will not always support intervention under Rule 24(a).

\footnotetext{
${ }^{10}$ Nuesse $v$ Camp, 385 F2d 694, 700 (DC Cir 1967), quoting Textile Workers Union $v$ Allendale Co., 226 F2d 765, 767 (DC Cir 1955).

${ }^{41}$ Reserve Mining, 56 FRD at 413. See also United States v Hooker Chemicals, 749 F2d 968, 983-85 (2d Cir 1984). Although both cases involved similar claims by environmental groups, their results differed according to the courts' interpretations of the relevant statute's effect on the inadequate representation requirement. In Reserve Mining the court granted the motion for intervention; in Hooker the court denied it.

${ }^{12}$ Keith, 764 F2d at 1268.

43 Id.

${ }^{4}$ See Sierra Club v Morton, 405 US 727, 734 (1972), quoting Hunt $v$ Washington State Apple Advertising Commission, 432 US at 343; United States v SCRAP, 412 US 669, 687-88 (1973). In both Sierra Club and SCRAP, the groups claimed standing under the Administrative Procedure Act. 5 USC § 702 (1982) (“APA"). 405 US at 732; 412 US at 685. The APA may confer standing in the absence of a legal wrong when a person is "adversely affected or aggrieved" by agency action. If so, Article III may not be broad enough to confer standing for non-economic and diffuse interests in the absence of a congressional directive such as the APA. See Sunstein, 88 Colum L Rev at 1440-41, 1474-80 (cited in note 34).

${ }^{45}$ United States $v 36.96$ Acres of Land, 754 F2d 855, 859 (7th Cir 1985).
} 
The Seventh Circuit's strict interpretation of the interest requirement, and its refusal to construe the requirement flexibly in public law cases, ${ }^{46}$ erects special barriers to intervention by public interest groups, whose interests by definition are not susceptible to direct injury in the same sense as those of traditional private parties. The court's decisions probably preclude intervention when an outsider claims a non-economic interest in an action. ${ }^{47}$ This poses special problems for environmental organizations, which generally assert aesthetic, conservational, or recreational interests. Moreover, the fact that litigation will affect an interest "intertwined" with a group's existence is irrelevant to the right to intervene in the Seventh Circuit. ${ }^{48}$ Thus, groups that have identified themselves with a certain cause or lobbied for a particular statute cannot intervene when the cause or statute is challenged.

In contrast to the Seventh Circuit, the Ninth Circuit generally evaluates motions for intervention without reference to whether the interests claimed are litigable. ${ }^{48}$ Interests found sufficient for intervention have included a wildlife group's interest in protecting birds and their habitats, a feminist organization's interest in the continued vitality of the Equal Rights Amendment, and a lobbying organization's interest in a statute that it sponsored. ${ }^{50}$ The Ninth Circuit has not clearly articulated the conditions under which an interest is "significant" within the meaning of Rule 24(a), but its opinions suggest that the connection between the public interest group and the particular litigation is an important factor. ${ }^{51}$

48 Keith, 764 F2d at 1268-69. But see id at 1272-73 (Cudahy dissenting) (arguing that "the interest factor must be broadly construed in 'public' cases").

${ }^{17}$ Id at 859.

${ }^{48}$ Keith, 764 F2d at 1269-70; and 36.96 Acres of Land, 754 F2d at 859. Compare Piedmont Heights Civic Club v Moreland, 83 FRD 153, 157 (N D Ga 1979).

40 See, for example, United States $v$ Stringfellow, 783 F2d 821, 826 (9th Cir 1986), vacated on other grounds, 480 US 370 (1987) (lower court decision to deny intervention as of right while allowing permissive intervention under Rule 24 is not immediately appealable); and Washington State Building \& Construction Trades Council v Spellman, 684 F2d 627, 630 (9th Cir 1982). See also Portland Audubon Society v Hodel, 866 F2d 302, 308 n 1 (9th Cir 1989).

so Sagebrush Rebellion, Inc. v Watt, 713 F2d 525, 526 (9th Cir 1982); State of Idaho v Freeman, 625 F2d 886, 887 (9th Cir 1980); and Washington Trades Council, 684 F2d at 627. As noted above, the Seventh Circuit has found similar interests insufficient for intervention. See 36.96 Acres of Land, 754 F2d at 859; and Keith, 764 F2d at 1268-69.

${ }^{81}$ In Stringfellow, 783 F2d at 823, the citizens' group was founded in response to hazardous waste releases at the defendant's plant; in Sagebrush Rebellion, 713 F2d at 526, the Audubon Society had supported creation of the challenged conservation area; in Washington Trades Council, 684 F2d at 629, the public interest group had sponsored the measure being challenged; and in Freeman, 625 F2d at 886, the National Organization for Women had lobbied for passage of the Equal Rights Amendment. 
The Ninth Circuit's interpretation of the Rule 24(a) interest requirement is superior to the Seventh Circuit's in its distinction between intervention and the standing and cause of action requirements. Courts should not equate a Rule 24(a) "significantly protectable" interest with a litigable interest because, as the Court emphasized in Trbovich, intervening in litigation raises different concerns from initiating litigation. ${ }^{52}$ An organization seeking to initiate a lawsuit threatens to impose much greater burdens on the court and on the defendant. In addition, Article III of the Constitution requires that the organization have suffered an injury from violation of a legal or constitutional right and that the controversy be justiciable. ${ }^{.3}$

When an organization moves to intervene in existing litigation, however, the original parties have already mobilized judicial resources. In this case the court's concern must shift to the policy

Contrast Portland Audubon, 866 F2d 302, which involved a challenge by environmental groups to the harvesting of certain timber. The Ninth Circuit denied intervention to several organizations with economic interests in continued harvesting because the relevant statute did not protect economic interests. Id at 309. In Stringfellow, Washington Trades Council, and Freeman, on the other hand, the group's members were within the class benefited by the relevant statutes.

In dicta in Portland Audubon, the Ninth Circuit panel expressed a view of the interest requirement much at odds with the views underlying other Ninth Circuit rulings, and claimed a harmony with the Seventh Circuit which must be viewed skeptically. In reconciling its approach with a Seventh Circuit decision involving the same statute, Wade $v$ Goldschmidt, 673 F2d 182 (7th Cir 1982), the Portland Audubon court cited with approval a footnote in Wade suggesting that intervention is inappropriate when the litigation "will not affect a statute or regulation governing the [outsiders'] actions, nor . . directly alter contractual or other legally protectable rights" of the outsider. $866 \mathrm{~F} 2 \mathrm{~d}$ at 309, quoting Wade, $673 \mathrm{~F} 2 \mathrm{~d}$ at $186 \mathrm{n}$ 6. But the motions for intervention that were granted in Sagebrush Rebellion, Washington Trades Council, and Freeman would not pass this test. In each case, the outsiders benefited from the legislation or procedures at issue, but were not governed by them. Nor did the outsiders have contractual or litigable rights that would be altered by the litigation.

More importantly, in Portland Audubon the Ninth Circuit cited but did not address the main argument in Wade - that only the government bodies charged with compliance to statutes can be sued for noncompliance. In Sagebrush Rebellion, the Ninth Circuit allowed a group to intervene on behalf of the government in a suit challenging the Secretary of Interior's compliance with procedures governing the withdrawal of public lands. For cases involving challenges to the constitutionality of statutes, contrast also Keith, 764 F2d at 1269, with Spellman, 684 F2d at 630 .

It is possible, of course, for the Ninth Circuit to change its view of intervention, but so dramatic a departure presumably would require an en banc decision; Portland Audubon is better understood as the product of one panel on a notoriously broad circuit.

${ }^{52}$ Trbovich, 404 US at 536 and note 7. See generally Shapiro, 81 Harv L Rev at 726-27 (cited in note 26); and Edward J. Brunet, A Study in Allocation of Scarce Judicial Resources: The Efficiency of Federal Intervention Criteria, $12 \mathrm{Ga} \mathrm{L} \mathrm{Rev} \mathrm{701,} \mathrm{725-26} \mathrm{(1978).}$

${ }^{83}$ Geoffrey R. Stone, et al, eds, Constitutional Law 76 (Little, Brown, 1986). A controversy is not justiciable if it is moot, premature, or involves a political question. 
issues associated with Rule 24(a): weighing the organization's interest against the interests of the original parties and the courts. ${ }^{54}$ Relevant statutes may aid the inquiry by indicating whether intervention is consistent with congressional intent, but the absence of a statutory right to bring suit should not automatically preclude intervention, because litigation may significantly affect outsiders even when they cannot bring an independent claim against either of the parties. ${ }^{55}$ This is particularly true in public law litigation, where the eventual decree will affect widespread interests.

\section{The inadequate representation requirement.}

Trbovich $v$ United Mine Workers ${ }^{66}$ is the only Supreme Court decision to squarely address the requirement of inadequate representation under Rule 24(a). In this case, the Secretary of Labor contended that he adequately represented the union member's interests in the proceeding. The Court disagreed with the Secretary, noting that an applicant need only show that "representation of his interest 'may be' inadequate; and the burden of making that showing should be treated as minimal." ${ }^{\text {"57 }}$ The Court held that the union member had satisfied this minimal burden because the Labor-Management Reporting and Disclosure Act imposed potentially conflicting duties on the Secretary-a duty to enforce union members' rights against their unions, and a duty to protect the public interest by assuring free and democratic union elections. Since the duties could dictate different approaches to the litigation, the Secretary's representation of the member's interests might be inadequate. ${ }^{58}$

The circuit courts have differed in their interpretation and application of Trbovich. They disagree primarily on the degree of inadequate representation an outsider must prove if it wishes to intervene on behalf of the government, as public interest groups often seek to do. In the leading appellate case, United States $v$

Br See Trbovich, 404 US at 536-37. See generally Kennedy, 57 Ky L J at 330-31 (cited in note 25).

ss Shapiro, 81 Harv L Rev at 726 (cited in note 26).

s8 404 US at 538 .

${ }^{37}$ Id at $538 \mathrm{n} \mathrm{10.} \mathrm{The} \mathrm{Second} \mathrm{Circuit} \mathrm{has} \mathrm{suggested} \mathrm{that} \mathrm{the} \mathrm{Court} \mathrm{mistakenly} \mathrm{based} \mathrm{its}$ minimal burden test on a pre-1966 version of Rule 24(a), even though Trbovich was decided in 1972. United States v Hooker Chemicals \& Plastics, 749 F2d 968, 986 n 16 (2d Cir 1984). The earlier version of the rule required a showing that representation "may be" inadequate, whereas the current version of the rule requires a showing that representation "is" inadequate. Id.

${ }^{88}$ Trbovich, 404 US at 538-39. 
Hooker Chemicals \& Plastics, ${ }^{58}$ the United States initiated an environmental enforcement action against the defendant corporation. Four environmental groups moved to intervene, claiming that their interests in the action were more focused than the government's interests. ${ }^{60}$ The Second Circuit distinguished Trbovich, where the Secretary acted pursuant to a statute that imposed conflicting duties, from Hooker, where the government was suing in its parens patriae capacity. Under the parens patriae concept, a governmental body is presumed to represent the public interest when it is a party to an action involving a matter of sovereign interest. ${ }^{61}$ Since the environmental groups in Hooker did not challenge the government's claim that it represented the public interest, they failed to "justify requiring only a 'minimal' burden to show possible inadequate representation." 22 Thus, "a strong showing of inadequate representation" was needed for intervention, which the groups failed to meet. ${ }^{63}$

The courts have not specified the type of strong showing that is needed to overcome this presumption of adequate representation. At a minimum, inadequacy of representation may be shown by proof of collusion between the representative and an opposing party; evidence that the representative's interest is adverse to that of the petitioner; or proof of nonfeasance by the representative. ${ }^{64}$ The Second Circuit indicated in Hooker that an outsider need not show collusion to intervene, explaining that " $a$ strong affirmative showing that the sovereign is not fairly representing the interests of the applicant" would meet the burden. ${ }^{65}$ Nonetheless, the showing required by the Second Circuit is almost certainly greater than in Trbovich, where the possibility of a different approach to the litigation was enough to satisfy the minimal burden test. ${ }^{66}$ Some

s9 749 F2d 968 (2d Cir 1984).

60 Id at 973-74.

81 Id at 987. Some courts have applied a similar presumption when public interest groups move to intervene on behalf of the government's defense of a statute or governmental action. See, for example, United Nuclear Corp. $v$ Cannon, 696 F2d 141, 144 (1st Cir 1982).

62749 F2d at 987.

${ }^{63}$ Id. See also United States $v$ City of Philadelphia, 798 F2d 81, 90 (3d Cir 1986). Bradley v Milliken, 828 F2d 1186, 1192 (6th Cir 1987) applies the presumption of adequate representation in a case with a nongovernmental plaintiff.

64 3B Moore's I 24.07[4] at 24.68-69 (cited in note 18). See also Wade v Goldschmidt, 673 F2d 182, 186 n 7 (7th Cir 1982).

65 Hooker Chemicals, 749 F2d at 985.

${ }^{68}$ Trbovich, 404 US at 539. For an example where the presumption of adequate representation was successfully rebutted, see Fleming $v$ Citizens for Albemarle, Inc., 577 F2d 236, 238-39 (4th Cir 1978). 
courts have also denied intervention as of right where the proposed intervenor claimed a more specialized interest, greater conviction or expertise, or where the intervenor would have argued the facts differently. ${ }^{67}$

As with the interest requirement, the Ninth Circuit takes a quite different approach to adequacy of representation. In United States $v$ Stringfellow, ${ }^{68}$ the Ninth Circuit specifically rejected the Second Circuit's analysis. Like Hooker, Stringfellow involved an environmental group seeking to intervene in an environmental enforcement action initiated by the United States. ${ }^{68}$ The Ninth Circuit applied the Supreme Court's "minimal burden" test and overturned the district court's denial of intervention. In applying the "minimal burden" test, the Ninth Circuit considered three factors: "whether the interests of a present party to the suit are such that it will undoubtedly make all of the intervenor's arguments; whether the present party is able and willing to make such arguments; and whether the intervenor would offer any necessary element to the proceedings that the other parties would neglect." Under this approach, assertions that the government might not prosecute claims as vigorously as the public interest group or that the public interest group offers expertise or a materially different perspective have justified intervention. ${ }^{71}$

The Ninth Circuit's approach to the inadequate representation requirement is probably a fairer reading of Trbovich. In Trbovich, the Supreme Court began its analysis by stating that Rule 24(a) requires only a minimal showing of inadequate representation. ${ }^{72}$ It was then that the Court turned to the Labor-Management Reporting and Disclosure Act, observing that the conflicting duties it imposed on the Secretary might dictate a different litigation approach from the union member's. ${ }^{73}$ In short, in Trbovich it was in light of the minimum burden requirement that the Secretary's conflicting duties became significant; it was not-as the Sec-

${ }^{67}$ See United Nuclear Corp., 696 F2d at 144; Keith, 764 F2d at 1270; and City of Philadelphia, 798 F2d at 90.

os 783 F2d 821, 827 (9th Cir 1986).

"9 Id at 823-24. The cases involved some of the same statutes.

20 Id at 827. Note that the Ninth Circuit has applied the same test when public interest groups move to intervene on behalf of the government's defense of a statute. See, for example, Sagebrush Rebellion, 713 F2d at 527-28; Washington Trades Council, 684 F2d at 630.

"See Stringfellow, $783 \mathrm{~F} 2 \mathrm{~d}$ at 828 (expressing concern that the original parties might "bargain away" the organization's interests since the organization asserted claims against both parties); and Sagebrush Rebellion, 713 F2d at 528.

Trbovich, 404 US at $538 \mathrm{n} 10$.

7s Id at 538-39. 
ond Circuit inferred-the Secretary's conflicting duties that gave rise to the minimum burden requirement. ${ }^{74}$

\section{Applying Rule 24(A) in the Public Law Context}

As noted in the previous section, Rule 24(a) aims at a balance between the interests of the outsiders, the original parties, and the courts. When a public interest group seeks to intervene in a public law case, new factors arise that alter this balance. After a brief description of these factors, this section will compare the relative weights of the three relevant interests in the private law context with their relative weights in the public law context.

\section{A. Intervention by Public Interest Groups as a Distinct Inquiry}

Public interest group intervention is a distinct inquiry from intervention generally for at least three reasons. First, public interest groups move to intervene almost exclusively in public law cases. ${ }^{75}$ This means that other parties have already made public policy an issue, and that the litigation's outcome is likely to affect the public interest group's members in the same way that it will affect the original parties. The question raised by a public interest group's desire to intervene in such a case is not the wisdom of complicating a private dispute with a public policy concern; that complication already exists. Once public policy has been made an issue, the question becomes whether it is in the interests of justice to exclude from the adjudication the expertise and advocacy that an interest group may bring to bear on the case.

${ }^{34}$ Hooker Chemicals, 749 F2d at 987 ("[a]ppellants have not pointed to anything like the conflicting statutory obligations imposed on the Secretary in Trbovich to challenge this claim and thus to justify requiring only a 'minimal' burden to show possible inadequate representation"). The distinction proves critical in cases where a public interest group can make a minimal, but not a higher showing of inadequate representation. Compare Sagebrush Rebellion, 713 F2d at 528; with Keith, 764 F2d at 1270, and City of Philadelphia, 798 F2d at 90.

${ }^{75} \mathrm{~A}$ search of Westlaw indicated that 171 federal appellate cases decided between February 7,1986 , and October 10,1989 , included the term "24(a)." In eleven of these cases the courts reviewed motions for intervention by public interest groups, and all can be characterized as public law cases (see text at notes 4-7). See United States v Metropolitan St. Louis Sewer District, 883 F2d 54 (8th Cir 1989); Harbor Against Land Takeover v United States Forest Service, 881 F2d 1083 (9th Cir 1989) (unpublished); Republican Party of North Carolina v Martin, 865 F2d 1259 (4th Cir 1988) (unpublished); Bradley v Milliken, 828 F2d 1186 (6th Cir 1987); City of Bloomington, Indiana v Westinghouse Electric Corp., 824 F2d 531 (7th Cir 1987); California ex rel State Lands Comm'n v United States, 805 F2d 857 (9th Cir 1986); United States v City of Philadelphia, 798 F2d 81 (3d Cir 1986); United States v LULAC, 793 F2d 636 (5th Cir 1986); EEOC v Nevada Resort Ass'n, 792 F2d 882 (9th Cir 1986); and United States v Stringfellow, 783 F2d 821 (9th Cir 1986). 
Second, public interest groups claim shared societal interests as their basis for intervention. An individual acting alone may not have a large enough stake in a particular environmental policy, for example, to justify the time and expense of intervention, but a public interest group is a "medium through which its individual members seek to make more effective the expression of their own views." "W6 While these organizations may have certain ideological biases, they nevertheless represent a pooling of capital, interests, and activities by individuals interested in vindicating similar policy concerns. ${ }^{77}$ Their significance thus lies in the breadth of interests represented by the organization as a whole.

Finally, public interest groups are often experts in the policy areas involved in the cases in which they seek to intervene. The three largest environmental organizations-the Natural Resources Defense Council, the Environmental Defense Fund, and the Sierra Club-depend on staff scientists to formulate policy and research the data upon which their cases rest. ${ }^{78}$ The Consumer Union, a national consumer law group, has its own product-testing laboratories. ${ }^{79}$ These and other organizations, like the NAACP and the ACLU, also develop expertise by focusing their efforts on particular areas of the law. ${ }^{\text {so }}$

\section{B. Interests of the Outsider}

The drafters of the 1966 amendments conceived of Rule 24(a) as a means of involving outsiders in litigation that might practically impair their interests. When litigation centers on private rights, the presence of a litigable interest provides one useful measure of the dispute's impact on the outsider. But the absence of a litigable interest does not foreclose the possibility that the dispute will significantly affect the outsider, particularly when litigation centers on public or regulatory policy that will affect a large number of outsiders, regardless of any legal rights they might have against the original parties. A court cannot order a city to rezone a

76 NAACP v Alabama ex rel Patterson, 357 US 449, 459 (1958).

${ }^{77}$ Automobile Workers v Brock, 477 US 274, 290 (1986). Public interest law organizations received $\$ 105.4$ million in contributions in 1983. Baum, Public Interest Law at 60 (cited in note 14). See also Council for Public Interest Law, Balancing the Scales of Justice at 90-94 (cited in note 14) (describing the division of contributions among various groups and causes).

${ }_{78}$ Council for Public Interest Law, Balancing the Scales of Justice at 118-19 (cited in note 13 ).

78 Id at 123.

${ }^{80}$ Id at 82-83, 100-32. 
residential area to accommodate low-income housing, or formulate an injunction to govern disposal of hazardous chemical wastes, without touching upon concerns of the community as a whole. ${ }^{81}$

Given this potential impact, representation of widespread public interests in public law cases becomes important for two reasons. First, resolution of a public law case usually depends on the court's evaluation of factual elements, such as the consequences of alternative schemes for correcting the substantive wrong. ${ }^{\mathbf{8 2}}$ While courts are experts on legal issues, they rely heavily on parties to provide the evidentiary foundation for factual issues. Consider the difficulty a court might face in formulating a decree to end race and sex discrimination in industrial hiring, or to govern a corporation's waste discharges, in the absence of information about the effect alternative resolutions will have on outsiders. ${ }^{83}$ Public interest groups have both the expertise and the motivation to ensure that shared societal values are considered. ${ }^{84}$

Second, the parties in public law cases often have extensive control over the formulation of the eventual decree, ${ }^{85}$ and without representation of outside interests in the negotiation process, the original parties may bargain away the interests of affected outsiders. Recent Justice Department school desegregation cases demonstrate what can go wrong when affected outsiders are denied a place at the bargaining table. Without the participation of groups representing minority parents-who wanted stricter remedies-the Department may have settled desegregation cases for much less than legally obtainable. ${ }^{86}$ Intervention by a public interest group

${ }^{81}$ See, for example, Joseph Skillken \& Co. v City of Toledo, 528 F2d 867, 874 (6th Cir 1975), vacated on other grounds, 429 US 1068 (1977), circuit court decision aff'd on remand, 558 F2d 350 (6th Cir 1977); and United States v Hooker Chemicals \& Plastics Corp., 749 F2d 968, 973 (2d Cir 1984).

${ }^{82}$ Chayes, 89 Harv L Rev at 1296 (cited in note 4).

${ }^{83}$ United States $v$ Allegheny-Ludlum Industries, Inc., 517 F2d 826 (5th Cir 1975); and United States v Reserve Mining Company, 56 FRD 408 (D Minn 1972).

84 See Automobile Workers, 477 US at 289.

${ }^{85}$ Chayes, 89 Harv L Rev at 1298-99 (cited in note 4).

${ }^{86}$ See Randolph D. Moss, Participation and Department of Justice School Desegregation Consent Decrees, 95 Yale L J 1811, 1812-14, 1828-29 (1986) ("the Attorney General acts more in accord with the role of representative of the Executive than as a representative of the victims of segregation"). The Justice Department has actually resisted participation by parents whose settlement views differ from the administration's. Id at 1814. See also Joel Selig, The Reagan Justice Department and Civil Rights: What Went Wrong, 1985 U Ill L Rev 785; and Stringfellow, 783 F2d at 828. Although non-participating parents may challenge these decrees in later suits, the decrees will only be vacated upon a showing that the remedial scheme violates a statutory or constitutional right of the parents or their children. See note 122 and accompanying text. 
may also reduce the pressure on the judge to fill gaps in proposed decrees that fail to account for the full range of interests affected by the litigation..$^{87}$

Other avenues do exist for presenting such concerns and information to the courts, but traditional alternatives to participation, such as amicus curiae status or reliance on governmental parties to represent public interests, are often insufficient in public law cases. Granting amicus status permits the public interest group a very limited role in the litigation. Amici do not participate in decree negotiations. More importantly, when a dispute centers on factual elements, "a party to the litigation is in a clearly superior position to insure that the range of issues and the evidence introduced in support of these issues conform to the viewpoint asserted by that party." 88 Only parties to a suit have the opportunity to engage in discovery. ${ }^{89}$ The very willingness of a public interest group to incur large court costs in order to intervene in a suit indicates the limits of amicus status in serving its interests.90

Even when the government is a party, it cannot always be depended upon to represent outsiders' interests. One might presume that since the United States Attorney General and state attorneys general are "charged with enforcement of the rights of the state," executive officials will fairly represent the public interest in suits when they act as parens patriae.$^{92}$ But the government is charged with representing varying interests, "industry as well as individuals," ${ }^{93}$ and when interests conflict or the government does not have

87 Chayes, 89 Harv L Rev at 1300 (cited in note 4).

88 Jones, 14 Harv CR-CL L Rev at 33 (cited in note 12) (emphasis added).

89 See Kennedy, $57 \mathrm{Ky} \mathrm{L}$ J at 367 (cited in note 25). See also Stringfellow, $783 \mathrm{~F} 2 \mathrm{~d}$ at 828 ("by engaging in independent discovery [the intervenor] might uncover facts that would affect the remedy in a manner favorable to it or would materially influence the settlement").

${ }^{\text {so }}$ Brunet, $12 \mathrm{Ga} \mathrm{L}$ Rev at 723, 729, 734 (cited in note 52). Because of these deficiencies, some courts have expanded the elements of amicus status in the public law area, permitting amici curiae to participate beyond mere brief writing. See, for example, Hooker Chemicals, 749 F2d at 992 (lower court offered amicus status plus the right to call and cross-examine witnesses); Hoptowit v Ray, 682 F2d 1237, 1260 (9th Cir 1982) (lower court gave amicus "full rights of parties to participate"); and SEC v Charles Plohn \& Co., 448 F2d 546, 549 (2d Cir 1971) (lower court allowed amicus to submit proof and be heard on oral argument). See generally Krislov, 72 Yale L J at 694 (cited in note 14). Though this receptiveness is commendable, when factual issues are important the aid that amici are thought to give the court is probably best furnished through intervention.

91 Vera Langer, Public Interest in Civil Law, Socialist Law, and Common Law Systems: The Role of the Public Prosecutor, 36 Am J Comp L 279, 296 (1988).

${ }^{\circ 2}$ See, for example, Hooker Chemicals, 749 F2d at 984-95; and United Nuclear Corp v Cannon, 696 F2d 141, 144 (1st Cir 1982).

${ }^{93}$ Reserve Mining Company, 56 FRD at 419. See also Richard B. Stewart, The Reformation of American Administrative Law, 88 Harv L Rev 1667, 1769 (1975). 
the resources necessary to represent all points of view, government counsel must choose among them. ${ }^{94}$

With discretion comes the potential for ideological bias. ${ }^{95}$ The Justice Department has been characterized as "the most politicized agency per capita in Washington." ${ }^{\text {96 }}$ In addition, government agencies can be subject to other forms of bias, such as the phenomenon of industry "capture." the effects of ideological bias in the executive branch, courts have largely ignored the problem by denying intervention to organizations representing the excluded interests. ${ }^{98}$ The Ninth Circuit's opinion in Sagebrush Rebellion v Watt ${ }^{99}$ stands as a marked contrast. Here, the court relied in part on a change in the Department of the Interior's political perspective and on the new Secretary's prior association with his opponents' legal counsel in holding that the public interest group met the "minimal burden" test of inadequate representation. Finally, even when unaffected by ideological bias, a government agency may simply pursue a valid claim with inadequate vigor or commitment.

\section{Interests of the Original Parties}

Courts have traditionally deferred to the right of original parties to control the direction of their lawsuit. ${ }^{100}$ In a private dispute,

94 Stewart, 88 Harv L Rev at 1770. See also Moss, 95 Yale L J at 1828-29 (cited in note 86) (noting that the Department of Justice cannot represent all possible interests in school desegregation cases).

os For examples of the impact of the Reagan Administration on regulating agencies and public law litigation, see Selig, 1985 U Ill L Rev at 785 (1985) (cited in note 86); Moss, 95 Yale L J at 1812-14 (cited in note 86); and Dorothy M. Bradley and Helen M. Ingram, Science vs. the Grass Roots: Representation in the Bureau of Land Management, 26 Natural Resources J 493, 495 (1986).

${ }^{86}$ Mitchell Rogovin, Reorganizing Politics Out of the Department of Justice, 64 ABA J 855, 856 (1978).

${ }^{97}$ Several recent books note that under President Reagan the EPA excluded environmental organizations from its policy making process, but sought advice from regulated industries. See Norman J. Vig and Michael E. Kraft, Environmental Policy in the 1980s: Reagan's New Agenda 22-23 (Congressional Quarterly, 1984); and Richard A. Harris and Sidney M. Milkis, The Politics of Regulatory Change: A Tale of Two Agencies 251-77 (Oxford, 1989).

${ }^{88}$ See United States $v 36.96$ Acres of Land, 754 F2d 855, 862 (7th Cir 1985) (dissent arguing that majority disregarded the possibility that the intervenor, not the plaintiff Interior Department, truly represented Congress's aim to preserve land in question); and United States v South Bend Community School Corp., 692 F2d 623 (7th Cir 1982) (court did not inquire into the Reagan Administration's record in the area of school desegregation).

89713 F2d 525, 528-29 (9th Cir 1983).

100 Jones, 14 Harv CR-CL L Rev at 39 (cited in note 12); and Weinstein, 13 UC Davis L Rev at 232 (cited in note 12). 
such control is the logical counterpart to the responsibilities imposed on the parties: the parties must initiate the legal action, define its issues, and develop the facts. ${ }^{101}$ Intervention threatens control because intervenors will usually introduce new evidence, new issues, and new positions on existing issues. ${ }^{102}$ Loss of control is particularly problematic for parties with limited resources who would like to limit the issues in a case through stipulations. New parties always bring with them new costs, and intervention may so strain resources that the original parties cannot afford to maintain the suit. ${ }^{103}$

But when a case affects widespread outside interests to the same extent that it affects the original parties, public interest groups often have a legitimate interest in ensuring that the court consider the full impact of its decision. Thus, parties who bring public law claims should not expect to maintain the same control over their litigation. ${ }^{104}$ When a claim is made in order to affect public or regulatory policy, the right of the original parties to control their lawsuit declines in importance. ${ }^{105}$

\section{Interests of the Courts}

Intervention affects the courts' interests in fair and efficient adjudication, both in the case at hand and in the court system as a whole. When an outsider claims a litigable interest, intervention may promote economy at a systematic level by avoiding duplicative suits, which waste resources, clog dockets, and frequently introduce the possibility of inconsistent judgments and complex collateral estoppel issues. ${ }^{106}$

Even when a public interest group asserts a non-litigable interest, intervention can offer considerable benefits in the case at

${ }^{101}$ Chayes, 89 Harv L Rev at 1283 (cited in note 4).

102 Jack H. Friedenthal, Increased Participation by Non-Parties: The Need for Limitations and Conditions, 13 UC Davis L Rev 259, 262-63 (1980); and Gene R. Shreve, Questioning Intervention of Right-Toward a New Methodology of Decisionmaking, $74 \mathrm{Nw}$ U L Rev 894, 908 (1980).

${ }^{103}$ Friedenthal, 13 UC Davis L Rev at 262-63; and Shreve, 74 Nw U L Rev at 909. Other legal doctrines do offer some protections to the original parties. For example, intervenors must have independent standing to appeal a judgment in the absence of the original party, and they cannot prevent a settlement between the original parties. See Diamond $v$ Charles, 476 US 54 (1986); and Local Number $93 v$ City of Cleveland, 478 US 502 (1986).

${ }^{104}$ Jones, 14 Harv CR-CL L Rev at 39 (cited in note 12).

${ }^{105}$ Weinstein, 13 UC Davis L Rev at 232 (cited in note 12). See also Brunet, $12 \mathrm{Ga} \mathrm{L}$ Rev at 745 (cited in note 52) ("The taxpayer subsidy of litigation detracts from the position that litigants hold 'rights.' ").

${ }_{106}$ Brunet, $12 \mathrm{Ga} \mathrm{L} \mathrm{Rev} \mathrm{at} \mathrm{719-20} \mathrm{(cited} \mathrm{in} \mathrm{note} \mathrm{52).}$ 
hand. It may promote better decisions by ensuring that critical information is available to the court. The original parties will not always produce the information necessary for just and accurate results; important information may be disadvantageous to both sides, of no concern to either, or too technical to be within their grasp. ${ }^{107}$ Public interest groups can fill the gap by showing the impact that a particular resolution may have on the interests that they represent. ${ }^{108}$ Additionally, as the Supreme Court has noted, "organizations often have specialized expertise and research resources relating to the subject matter of the lawsuits that individual plaintiffs lack."109

Permitting intervention by those with interests affected by a pending judgment also serves the courts by supporting their own legitimacy. The legitimacy of judicial action depends partly on the appearance of fairness. ${ }^{110}$ Judicial decisions that affect widespread interests may be more likely to be viewed as illegitimate when courts fail to provide persons affected by the decision with a right to be heard "before their fate is sealed."111 Giving outsiders a sense of participation in the process is important; "[a]ccess to the legal process . . . is a logical extension of realistic awareness of law as a process of social choice and policy making."112

107 See Stringfellow, $783 \mathrm{~F} 2 \mathrm{~d}$ at 828. See also Brunet, $12 \mathrm{Ga} \mathrm{L} \mathrm{Rev} \mathrm{at} \mathrm{729-31} \mathrm{(cited} \mathrm{in}$ note 52); and Chayes, 89 Harv L Rev at 1297-98 (cited in note 4).

108 Bryden, 66 Can Bar Rev at 507-08; and Jones, 14 Harv CR-CL L Rev at 42-43 \& n 48 (cited in note 12).

${ }^{108}$ Automobile Workers $v$ Brock, 477 US 274, 289 (1986), quoting Note, From Net to Sword: Organizational Representatives Litigating Their Members' Claims, 1974 U Ill L F 663, 669 (1974). See also Natural Resources Defense Council v United States Nuclear Regulatory Commission, 578 F2d 1341, 1346 (10th Cir 1978); Natural Resources Defense Council $v$ Tennessee Valley Authority, 340 F Supp 400, 408-09 (S D NY 1971), rev'd on other grounds, 459 F2d 255 (2d Cir 1972); and Weinstein, 13 UC Davis L Rev at 232, 246 (cited in note 12$)$.

Of course, public interest intervenors do not just provide information; like all litigants, they provide information that supports their position. But the fact that public interest groups now represent both ends of the political spectrum mitigates the danger that facilitating intervention will introduce uniform ideological biases in judicial decisions. Baum, Public Interest Law at 44-48, 55-56 (cited in note 14). See also Joel F. Handler, Ellen Jane Hollingsworth, and Betsy Ginsberg, Organizations and Legal Rights Activities 13-16 (U Wisconsin, 1974). More importantly, unlike legislative lobbying, which employs political pressure to achieve desired ends, public interest group intervention calls on the power of ideas to persuade a court.

${ }^{110}$ In Chayes's words, "[J]udicial action only achieves [] legitimacy by responding to . . . the demand for justice in our society." 89 Harv L Rev at 1316 (cited in note 4). See also Antonin Scalia, The Rule of Law as a Law of Rules, 56 U Chi L Rev 1175, 1178 (1989) (discussing the importance of the "appearance" of justice to courts' legitimacy).

11 Weinstein, 13 UC Davis L Rev at 232 (cited in note 12).

112 Krislov, 72 Yale L J at 721 (cited in note 14). See also Weinstein, 13 UC Davis L 
Of course, to justify intervention the systemic and individual case benefits must outweigh the burdens imposed by the addition of a new party. As one court has stated, "[a]dditional parties always take additional time. Even if they have no witnesses of their own, they are the source of additional questions, objections, briefs, arguments, motions and the like ...."113 The fact that an outside group wants to intervene suggests that it disagrees with an original party's strategy, so the group will be more likely to request its own pleadings, objections, and discovery, which will further complicate the proceedings. ${ }^{14}$ The problem of added complexity is particularly acute in public law cases, where the litigation is already "extraordinarily complex," many outsiders are significantly affected, and greater judicial supervision is needed. ${ }^{115}$

Although these determinations must be made on a case-bycase basis, Judge Weinstein, a veteran of "at least a score" of public law cases, doubts that liberality in granting intervention "will produce costs in terms of complexity that outweigh the advantage of access to the courts by those who may be affected by the judicial decisions." 116 Relatively few affected outsiders actually want to appear in court, and most of those who do willingly accept reasonable limits on their participation. ${ }^{117}$

\section{A Proposed ApPROACH}

Since the interests of public interest group intervenors in public law litigation differ from those of individual intervenors in private disputes, a construction of Rule 24(a) that treated both situations the same would defeat the drafters' emphasis on practicality. ${ }^{118}$ When a public interest group seeks to intervene in a private dispute, courts can legitimately impose the same requirements they would upon private individuals. The dispute will center on private rights rather than public policy, so the burden imposed

\footnotetext{
Rev at 232 (cited in note 12); and Bryden, 66 Can Bar Rev at 508-10 (cited in note 108).

11 Crosby Steam Gage \& Valve Co. $v$ Manning, Maxwell \& Moore, Inc., $51 \mathrm{~F}$ Supp 972, 973 (D Mass 1943). See also Stadin v Union Electric Co., 309 F2d 912, 920 (8th Cir 1962); and Jones v United Gas Improvement Corp., 69 FRD 398, $402-03$ (E D Pa 1975).

114 Dennis A. Kendig, Procedures for Management of Non-Routine Cases, 3 Hofstra L Rev 701, 705-06 (1975).

${ }^{115}$ Chayes, 89 Harv L Rev at 1291, 1298 (cited in note 4). See also Sagebrush Rebellion, 713 F2d at 531 (Wallace dissenting).

116 Weinstein, 13 U C Davis L Rev at 246 (cited in note 12).

117 Id. See note 148 and accompanying text.

118 See 1966 Advisory Committee Note, reproduced in 3B Moore's If 24.01[10] at 24.1124.13 (cited in note 18).
} 
by the group's intervention will probably outweigh any benefit. ${ }^{119}$ But when a public interest group moves to intervene in a public law suit, the appropriateness of intervention will depend on the litigation's potential effect on the organization's members, the connection between the organization's purposes and the subject of the litigation, the nature of the controversy, any relevant statutory scheme, and the degree to which the original parties fail to represent outside interests. This section provides a framework for considering these factors.

\section{A. Re-examining the Interest Requirement}

When a public interest group asserts a litigable interest, the court should usually grant its motion for intervention. Public interest groups have demonstrated both the willingness and the ability to initiate litigation; thus, denying their motions for intervention risks duplicative suits and possibly inconsistent results, or impeding the group's ability to pursue its own legal or constitutional claims. ${ }^{120}$ The costs of duplicative suits are especially troublesome in the public law context, where multiple issues and other complexities already strain court time and party resources. ${ }^{121}$ Moreover, a second suit poses a great risk of inconsistent and conflicting decrees: a court cannot desegregate a school or structure a hazardous waste program under two different plans. Thus, the original suit may establish the remedial scheme for all practical purposes. ${ }^{122}$ In sum, when the litigation is complex and an affirmative decree likely, a litigable interest should be sufficient for intervention.

${ }^{110}$ See, for example, Westlands Water Dist. $v$ United States, 700 F2d 561, 563 (9th Cir 1983). In this case, the Ninth Circuit departed from its liberal construction of Rule 24(a) and denied an environmental group's motion for intervention because "the contracts and not public policy . . . are at issue." Id.

${ }^{120}$ See text accompanying notes $37-38$.

121 Sagebrush Rebellion v Watt, 713 F2d 525, 531 (9th Cir 1983) (Wallace dissenting).

122 Although nonparties to a consent decree can collaterally attack the decree when they have "conflicting claims" to those of the parties of the decree, Martin $v$ Wilks, $109 \mathrm{~S}$ Ct 2180, 2183-84, 2188 (1989), a second court will only vacate the original decree when it violates the challengers' rights under the Constitution or a statute. Thus, the possibility of a subsequent attack is often insufficient to protect outsiders who have a clear interest in the remedial scheme and who would like to affect the manner in which a constitutional or statutory mandate is implemented. See United States v Stringfellow, 783 F2d 821, 827 (9th Cir 1986); and Johnson v San Francisco United School District, 500 F2d 349, 353 (9th Cir 1974). See also Natural Resources Defense Council v Castle, 561 F2d 904, 910-11 \& n 35 (9th Cir 1977). 
When a public interest group asserts a non-litigable interest as its basis for intervention, other factors may still indicate a sufficient stake in the litigation to warrant intervention. Unlike an individual intervenor, a public interest group has two types of interests when it seeks to intervene in a suit. First, it is interested as a representative of its members. By pooling the resources of individuals who share similar policy concerns, a group can be heard even if high court costs would preclude intervention by individual members. ${ }^{123}$

Second, a public interest group has an interest as an organization. Often, this interest arises from a direct connection to the controversy that gave rise to the litigation, as when the organization sponsored challenged legislation or formed in response to a particular environmental hazard. ${ }^{124}$ In other cases, the organization has an interest because of its connection with a legal principle at issue in the case. For example, the ACLU has long been associated with First Amendment issues, and the NAACP with advancing the legal rights of blacks. ${ }^{125}$ In either situation, the organization's interest evidences a commitment to the litigation in which it seeks to intervene.

This second interest is an important factor in intervention decisions even when an organization brings suit in its representative capacity. The Supreme Court has said that when an association wants to initiate a claim on behalf of its members it must show that the "interests it seeks to protect are germane to the organization's purpose," 126 reasoning that "[ $t]$ he very forces that cause [them] to band together in an association will thus provide some guarantee that the association will work to promote their interests."127 This reasoning applies equally in the intervention context. In addition, the nexus between a group's purposes and the litigation in which it moves to intervene usually indicates the group's ability to provide specialized and technical information. ${ }^{128}$

In sum, public interest groups should be allowed to intervene in lawsuits as representatives of their members for the same rea-

${ }^{123}$ Bryden, 66 Can Bar Rev at 507-08 (cited in note 108).

124 See cases cited in note 51.

125 Baum, Public Interest Law at 49-51 (cited in note 14). For examples of this type of interest, see United States $v$ South Bend Community School Corp., 692 F2d 623, 628 (7th Cir 1982) (NAACP); and State of Idaho v Freeman, 625 F2d 886, 887 (9th Cir 1980) (NOW).

${ }^{126}$ Hunt $v$ Washington State Apple Advertising Comm'n, 432 US 333, 343 (1977).

${ }^{127}$ Automobile Workers, 477 US at 290.

${ }^{128}$ Id at 289. 
sons that they may now initiate lawsuits on behalf of their members. The difference is the type of interest that is relevant in each context. Thus, by analogy to the associational standing doctrine, ${ }^{129}$ a public interest group should have the ability to intervene in a lawsuit when (a) its members have an interest relating to the property or transaction that is the subject of the action and are so situated that disposition of the action may as a practical matter impair or impede their ability to protect that interest; (b) the interest it seeks to protect is germane to the organization's purpose; (c) neither the claim asserted nor the relief requested requires the participation of individual members in the lawsuit; and (d) the interest is not adequately represented by existing parties. ${ }^{\mathbf{1 3 0}}$

The associational standing doctrine is not without its critics. These opponents argue that the doctrine prevents organizations without injured members from litigating, creates mootness problems when injuries are short-lived, and discourages courts from recognizing standing when there are possible conflicts of interest between members and leadership. ${ }^{131}$ The most frequent criticism is that associational standing is a fiction that forces groups to "play the standing game by artificial rules" and rewards clever legal drafting. ${ }^{132}$ Even when an organization claims injury to its members, the real party in interest is the organization itself, which serves as legal counsel and supervises the litigation. ${ }^{133}$ These criticisms apply equally to an analogous associational intervention doctrine.

But there are reasons why such a doctrine makes sense, at least in the context of intervention. Those who defend public law litigation ground its legitimacy in the notion that these cases address and determine national policy through specific controversies. ${ }^{134}$ Allowing outsiders to intervene on the basis of policy concerns rather than as representatives of affected or injured members undermines this institutional advantage. The drafters of the 1966 amendments to Rule 24(a) clearly sought to protect outsiders against possible adverse effects; they did not intend merely to pro-

128 The requirements for associational standing are set forth in the text at note 35 .

130 Compare this test with the doctrine of associational standing enunciated in Hunt, 432 US at 343 , and Rule 24(a).

132 Burnham, 20 Harv CR-CL L Rev at 164-68 (cited in note 9).

132 Orren, $70 \mathrm{Am}$ Pol Sci Rev at 738 (cited in note 14). See also Burnham, 20 Harv CR-

CL L Rev at 167-68.

${ }^{133}$ Burnham, 20 Harv CR-CL L Rev at 168.

${ }^{134}$ Chayes, 89 Harv L Rev at 1308 (cited in note 4). 
vide a channel for advocacy of abstract policy positions. ${ }^{135}$ In addition, the informational and legitimating benefits associated with public interest group intervention depend largely on the fact that the group acts as a representative of affected outsiders. Finally, intervention by public interest groups and standing for public interest groups should be treated similarly. The situations are analogous and raise similar concerns. The Supreme Court's recent reaffirmation of associational standing in Automobile Workers $v$ Brock ${ }^{136}$ demonstrates its commitment to the doctrine's principles.

But the larger problem remains. Acceptance of an associational intervention doctrine does not indicate the type of non-litigable interest that should suffice for intervention. ${ }^{137}$ Several guidelines seem appropriate, at least in the context of intervention by public interest groups.

First, courts should evaluate the group's interest with reference to the nature of the particular controversy. Courts and commentators agree that Rule 24(a) is fundamentally a balancing test-its interest, impairment, and inadequate representation requirements attempt to identify those situations in which an outsider's interests tip the scales in favor of intervention. ${ }^{138}$ Thus, courts should recognize that the relative weights of the outsider's interests, the original parties' interests, and the court's interests are different in the public law context. When litigation centers on public rights, such as the right to desegregated schools or a clean environment, its resolution is likely to affect outsiders to the same extent as the original parties. If the court's interests also favor intervention, then intervention may be consistent with Rule $24(\mathrm{a}) .^{138}$ In sum, courts cannot consider an outsider's interest in the abstract; instead, they should evaluate the strength of the interest relative to the other interests at stake in the litigation.

\footnotetext{
1951966 Advisory Committee Note, reproduced in 3B Moore's 1 24.01[10] at 24.11-24.13 (cited in note 18).

136 477 US at $289-90$.

137 This problem remains unanswered even in the context of private motions for intervention. As Professor Moore reports, "The exact nature of the interest required to sustain a right to intervene has eluded a precise and authoritative judicial definition ...." $3 B$ Moore's 24.07[02] at 24.57 (cited in note 19).

${ }^{138}$ See Hooker Chemicals, 749 F2d at 982. See also 3B Moore's If 24.07[1] at 24.5224.53; Shapiro, 81 Harv L Rev at 739-740 (cited in note 25); and Kennedy, $57 \mathrm{Ky} \mathrm{L} \mathrm{J} \mathrm{at} \mathrm{330-}$ 31 (cited in note 25).

${ }^{139}$ These policy considerations seem to underlie the DC Circuit's decision in Nuesse $v$ Camp, 385 F2d 694, 700 (DC Cir 1967), and the District of Minnesota's decision in United States v Reserve Mining Co., 56 FRD 408, 412-13 (D Minn 1972). Both courts emphasized the importance of construing the interest requirement differently in the public law context.
} 
Second, courts should consider the effect of any relevant statutory schemes. The Seventh Circuit, along with other circuits that require a litigable interest for intervention, mistakenly analyzes statutes only in terms of whether they vest outsiders with legal rights. ${ }^{140}$ This emphasis on legal rights is incomplete because initiating a lawsuit raises different concerns from intervening in a lawsuit. ${ }^{141}$

Differences in statutes may justify seemingly inconsistent results in similar situations. Hooker Chemicals and Reserve Mining Company are illustrative. In both cases, environmental groups moved to intervene in suits brought by the federal government to enforce environmental statutes. In Hooker Chemicals, the government brought suit under the emergency power provisions of the Clean Water Act, the Resource Conservation Recovery Act, and the Safe Drinking Water Act. ${ }^{122}$ After extensive statutory analysis, the Second Circuit denied the motions for intervention, relying on the fact that Congress " "carefully restricted' the rights of private persons to bring or to intervene in actions of this sort" in order to maintain governmental control over water quality standards and to provide the Administrator with necessary flexibility. ${ }^{143}$ However, in Reserve Mining Company, the government brought suit under the Water Pollution Control Act. ${ }^{144}$ Here, the court granted numerous motions for intervention because the statute placed it in the role of "an administrative tribunal" and required it to consider a multiplicity of interests. ${ }^{145}$

\section{B. Re-examining the Inadequate Representation Requirement}

Because the Supreme Court's jurisprudence regarding the inadequacy of representation requirement is unclear, policy considerations are especially important in choosing the appropriate test for public interest group intervention on behalf of the government. The appropriate showing of inadequate representation rests on a choice between presumptions. The Second Circuit requires a high

${ }^{140}$ See text at notes $42-48$.

${ }^{142}$ See text at notes 52-54; and see Trbovich, 404 US at 536-37. See also Smuck v Hobson, 408 F2d 175, 179 (DC Cir 1969). See generally Shapiro, 81 Harv L Rev at 726-27 (cited in note 25$)$.

${ }_{142}$ Hooker, $749 \mathrm{~F} 2 \mathrm{~d}$ at $970-71$.

${ }^{143}$ Id at $987-88$. But for a criticism of the court's analysis of the inadequacy of representation requirement, see text at notes 72-74.

14456 FRD at 413.

${ }^{145}$ Id. See also Bennett v Madison County Board of Education, 437 F2d 554, 556-57 (5th Cir 1970) (Wisdom dissenting). 
showing of inadequate representation because it presumes that the government adequately represents public interests. Professor Edward Brunet takes a different approach, reasoning that a lower showing should suffice because willingness to intervene despite large court costs suggests that the intervenor believes that it can add something to the proceedings that will justify the expense. ${ }^{146}$

Professor Brunet's presumption seems especially appropriate where public interest groups and public law litigation are involved. Unlike individual intervenors, public interest groups usually have multiple opportunities for intervention. Thus, they have an incentive to target the cases where their policy concerns are least represented. Moreover, public law cases often involve politicized issues like school desegregation, environmental policy, and the constitutionality of statutes restricting abortion or prohibiting discrimination on the basis of sexual orientation. Thus, the government may fail to represent a public interest group's concerns even in the absence of bad faith, collusion, or failure to fulfill its duty. If a court can limit intervention to minimize intrusiveness, as discussed below, then there is little reason to require a strong showing of inadequate representation.

\section{Limiting Intervention}

The drafters of the 1966 amendments to Rule 24(a) noted that courts may subject intervention of right to "appropriate conditions or restrictions responsive among other things to the requirements of efficient conduct of the proceedings." 147 Several courts have relied on this comment to limit their grants of intervention. For example, courts have limited the issues that an intervenor may raise, denied intervenors the right to a jury trial, limited intervention to a particular stage of the trial, and required that multiple intervenors use restricted numbers of spokesmen and combine discovery and motion presentations. ${ }^{148}$ Limited intervention is a useful tool

\footnotetext{
14 Brunet, $12 \mathrm{Ga} \mathrm{L} \mathrm{Rev} \mathrm{at} \mathrm{723,} \mathrm{729-30,} \mathrm{734-35} \mathrm{(cited} \mathrm{in} \mathrm{note} \mathrm{52).} \mathrm{See} \mathrm{also} \mathrm{Holmes} v$ Government of Virgin Islands, 61 FRD 3, 5 (D VI 1973).

1471966 Advisory Committee Note, reproduced in 3B Moore's If 24.01[10] at 24.13 (cited in note 18).

14 See, for example, Van Hoomissen $v$ Xerox Corp., 497 F2d 180, 181-82 (9th Cir 1974) (affirming trial court's limit of intervention under Rule 24(b) to issue of retaliation); Abbotts Dairies Division of Fairmont Foods, Inc. $v$ Butz, 421 F Supp 415, 419 (E D Pa 1976) (allowing intervention under 24(b) only on issue of damages); United States v Massachusetts Bonding \& Insurance Co., 303 F2d 823 (2d Cir 1962) (affirming trial court's grant of intervention under $24(\mathrm{~b})$ on the condition that the intervenor waive its right to a jury trial); United States $v$ American Telephone \& Telegraph Co., 642 F2d 1285, 1290-94 (DC Cir
} 
because it allows courts to incorporate the benefits of intervention yet minimize complications, delays, and added expenses. ${ }^{149}$

Because flexibility is especially important in public law cases, courts should condition grants of intervention to public interest groups on their consent to reasonable limits when necessary to ensure manageability. ${ }^{150}$ Several factors may be helpful in determining the extent to which the group should become involved in a case. A public interest group poses a stronger case for full party rights when it has a litigable interest. If an organization claims a statutory or constitutional right, its interest undoubtedly deserves the court's protection. ${ }^{151}$ Public interest groups also have a stronger case for full party rights when the interests that they advance are completely unrepresented by existing parties. In the absence of government involvement in a suit, intervention by a public interest group may provide the information necessary for a just result. When the government is a party to a dispute involving a matter of sovereign interest, public interest group participation is only necessary to the extent that it adds a different perspective, provides specialized information and vigor, or legitimizes the decision making process.

Many commentators have already called for a more flexible approach to intervention. They would provide a set of relevant fac-

1980) (allowing intervention under 24(a) for the limited purpose of appealing a collateral issue); Bradley $v$ Milliken, 620 F2d 1141, 1142-43 (6th Cir 1980) (allowing intervention under 24(b) at remedial phase for the limited purpose of presenting historical evidence); Fox v Glickman Corp., 355 F2d 161, 164-65 \& n 3 (2d Cir 1965) (denying intervention under 24(b) but noting that petitioner might be entitled to intervene at remedial phase if defendant's liability were later to be established); and Reserve Mining, 56 FRD at 420 (allowing intervention under 24(a) by multiple applicants but requiring a single spokesman during pretrial hearings for each intervenor, combined discovery, uniform presentation of motions, agreements on witnesses and evidence whenever possible, and use of the original parties' attorneys as liaison).

Like restrictions on parties, restrictions on intervention are not immediately appealable but may be challenged after trial. See generally Stringfellow $v$ Concerned Neighbors in Action, 480 US 370, 376-77 \& $\mathrm{n} 6$ (1987); and id at 382-83 (Brennan concurring). In addition, if the restrictions have the practical effect of denying the intervenor a right to participate, and postjudgment appeal is likely to be ineffective, the intervenor may probably petition for a writ of mandamus. Id at 381 (Brennan concurring). Note that a court has less discretion in limiting intervention of right than it does in limiting permissive intervention. Id at 381-82.

${ }^{249}$ See Shapiro, 81 Harv L Rev at 753-56 (cited in note 25); and Brunet, $12 \mathrm{Ga} \mathrm{L} \mathrm{Rev} \mathrm{at}$ 743-44 (cited in note 52).

${ }^{360}$ Judge Weinstein reports that limiting intervention is "entirely practicable," and that most parties will accede to reasonable limits on participation. 13 UC Davis L Rev at 246 (cited in note 14).

${ }_{151}$ Note that intervenors with litigable interests may be barred from asserting those interests in future suits under the doctrine of res judicata. Thus, placing undue restrictions on participation may present fairness problems. See note 122 and accompanying text. 
tors and leave intervention largely to the discretion of the trial judge under Rule 24(b). ${ }^{152}$ But there is a difference between flexibility in allowing intervention under Rule 24(b) and flexibility in limiting intervention under Rule 24(a). To be sure, discretion at either level leaves room for arbitrary decisions; a judge who disagrees with a public interest group's viewpoint can block its participation almost as effectively by severely limiting intervention as by denying intervention altogether. However, the two approaches lead to different presumptions. Making the initial intervention decision discretionary establishes a presumption that the public interest group may not belong in the litigation. By contrast, allowing participation with discretionary limits indicates that the group has some right to assert its interests in the litigation but that the court may balance this right against judicial manageability. In addition, the reason that public interest groups move to intervene-to protect outside interests-more closely accords with the theory behind intervention of right.

\section{Conclusion}

Because the interests balanced by Rule 24(a) are of different relative weights in public law cases and private law cases, courts should distinguish the two situations. Rule 24(a) as written can accommodate public interest group intervention if courts are willing to construe its requirements flexibly in the public law context. First, a court should evaluate the interests of the group's members in light of the nature of the controversy and any relevant statutes. Second, it should examine the connection between the group and the subject of the litigation. If the court determines that the group's members have a sufficient interest in the litigation and that the group has an appropriate connection to the litigation, it should then apply the Trbovich minimal burden test of inadequate

182 See, for example, Brunet, $12 \mathrm{Ga} \mathrm{L} \mathrm{Rev} \mathrm{at} \mathrm{718,} \mathrm{742-45} \mathrm{(cited} \mathrm{in} \mathrm{note} \mathrm{52)} \mathrm{(achieving}$ maximum efficiency requires allowing the judge to decide when the benefits of intervention outweigh its costs); Shapiro, 81 Harv L Rev at 758, 761-63 (cited in note 25) (would permit intervention of right only when a statute grants the right to intervene, the applicant is a member of a class under Rule 23 , or the applicant is a necessary party under Rule 19 (a)(2)(i), and would leave permissive intervention to the court's discretion based on a list of six relevant factors); and Shreve, $74 \mathrm{Nw} \mathrm{L} \mathrm{Rev} \mathrm{at} \mathrm{924-27} \mathrm{(cited} \mathrm{in} \mathrm{note} \mathrm{102)} \mathrm{(would} \mathrm{use}$ the same factors as Professor Shapiro but would submit all motions for non-statutory intervention to the discretion of the court). Contrast Jones, 14 Harv CR-CL $L$ Rev at 47-48 (cited in note 14) (proposing creation of a class of applicants whose intervention is not discretionary, on the grounds that intervention decisions may depend on the court's sympathy to the underlying claim) and Friedenthal, 13 UC Davis L Rev at 262 (cited in note 102) (would limit opportunities for intervention). 
representation even when the public interest group moves to intervene on behalf of the government. These initial steps may be undertaken under the framework of an associational intervention doctrine analogous to the current associational standing doctrine. Finally, the court should condition any grant of intervention on the group's consent to reasonable limits when necessary to ensure manageability. ${ }^{153}$

${ }^{153}$ Reserve Mining, 56 FRD at 408 , exemplifies this approach. The court began by recognizing that the relevant statute gave it a role much like an administrative tribunal. Id at 413. Given this statutory role, the court viewed Rule 24(a)'s interest and inadequate representation requirements as favoring inclusion. Id. It allowed several environmental groups to intervene in the litigation on behalf of the government because their environmental interests were more specific than the government's. Id at 417-20. However, the court limited the grants of intervention in order to ensure manageability. Id at 420 . 